\title{
Overseas Investors in the U.S. Insurance Market
}

\author{
by John O. Nigh*
}

\section{Introduction}

We will review in this paper the recent acquisition activity, what's happening in the U.S. insurance market, and provide an overview of the current status of the life/health insurance and the property/casualty insurance markets, why acquisitions are being made by overseas investors and then, finally, how these acquisitions are made.

\section{Recent activity}

Table 1:

Insurance acquisitions in the U.S.

\begin{tabular}{|l|l|l|}
\hline \multicolumn{1}{|c|}{ Target } & \multicolumn{1}{|c|}{ Acquisitor } & \multicolumn{1}{|c|}{ Purchase Price } \\
\hline Farmers Group & BAT Industries plc & $\$ 5,250$ million \\
\hline BAT Industries plc & $\begin{array}{l}\text { Hoylake Investments } \\
\text { (Sir James Goldsinith) }\end{array}$ & $\begin{array}{l}\$ 4,500 \text { million } \\
\text { (Farmers) }\end{array}$ \\
\hline Maccabees Mutual Life Insurance Co. & Royal Insurance Holdings & $\$ 110$ million \\
\hline Inter-State Assurance Co. & Irish Life PLC & $\$ 30$ million \\
\hline Integrity Life Insurance Co. & National Mutual Life & $\$ 160$ million \\
\hline $\begin{array}{l}\text { Business Men's Assurance Company } \\
\text { of America }\end{array}$ & Generali-Assicurazioni & $\$ 285$ million \\
\hline General Casualty Companies & Winterthur Swiss Insurance Co. & $\$ 630$ million \\
\hline $\begin{array}{l}\text { Virginia Life Insurance Company } \\
\text { of New York }\end{array}$ & $\begin{array}{l}\text { Cooperants Mutual Life } \\
\text { Insurance Society }\end{array}$ & Not disclosed \\
\hline $\begin{array}{l}\text { Washington National Insurance Co. } \\
\text { (Home service business) }\end{array}$ & AEGON NV & $\pm \$ 110$ million \\
\hline Fireman's Fund Insurance Co. & Allianz AG & $\pm \$ 3.1$ billion \\
\hline Western Reserve Life Assurance Co. & AEGON NV & $\pm \$ 65$ million \\
\hline Equitable Life & Axa Midi & $\pm \$ 1000$ inillion \\
\hline Lamar Life Insurance Co. & Whitehall Insurance Holdings & $\$ 130$ million \\
\hline Providence Washington Insurance Co. & Baloise Insurance & Not disclosed \\
\hline Southern Guaranty companies & Winterthur Insurancc Group & Not disclosed \\
\hline First Insurance Company of Hawaii (40\%) & Tokio Marine \& Fire & $\pm \$ 27$ million \\
\hline Maryland Casualty Co. & Zurich Insurance & $\pm \$ 740$ million \\
\hline Southland Life Insurance Co. & Nationale-Nederlanden & $\$ 434$ million \\
\hline Life Insurance Company of the Southwest & LSW Holding Co. & $\$ 71$ million \\
\hline
\end{tabular}

* Tillinghast, Atlanta, USA. Study presented at the Second Geneva International Forum on Global Services and Trade Liberalization, Geneva, May 22, 1991. 
Going back to 1988, we look at BAT's acquisition of Farmers Group. This initially began as a hostile acquisition which subsequently turned out to be a friendly acquisition as BAT agreed to increase their purchase price from what started out to be around $\$ 4$ billion, with the final price in excess of $\$ 5$ billion. BAT encountered severe regulatory hurdles and one must wonder whether or not they would have been successful had it not turned into a friendly acquisition. No sooner had the dust settled on BAT's acquisition did Hoylake, whose majority owner is Sir James Goldsmith, attempt to acquire BAT. Sir James arranged a premarriage agreement with Axa Midi who intended to immediately acquire Farmers Group should Sir James be successful in his acquisition. The pre-arranged purchase price was $\$ 4.5$ billion which compares to $\$ 5.25$ billion that BAT had paid months earlier. The same regulatory hurdles faced Hoylake and the attempt was subsequently disapproved when the California Department turned down the acquisition because of concerns over the structure of the acquisition.

Royal Insurance acquired Maccabees through a structured demutualization for $\$ 110$ million. More examples are Inter-State's acquisition by Irish Life and National Mutual's acquisition of Integrity from Equitable Assurance Company. Interestingly, both companies were previously owned by mutual companies in the United States and with Inter-State having previously been acquired through a structured demutualization.

BMA was acquired by Generali. Winterthur acquired General Casualty Companies for $\$ 630$ million. Again, we have several other examples up here with the biggest remaining one being Allianz' acquisition of Fireman's Fund for $\$ 3.1$ billion. Finally, NationaleNetherlanden bought Southland Life for $\$ 434$ million.

Who have been the largest buyers of U.S. companies? Clearly, the foreign buyers that stand out are the Dutch and, in particular, AMEV, AEGON, and Nationale-Netherlanden.

Other countries on the list which, by the way, is not meant to be all inclusive, but the countries that do come to mind include Australia, France, Germany, Ireland, Italy, Sweden, Switzerland and of course, the United Kingdom.

Of special note would be Japan. On the property and casualty side, several Japanese companies have branches or subsidiaries in the U.S. such as Tokio Marine and Fire which owns two companies. On the life side, this has not been as prevalent. Meiji Mutual is the only Japanese life company to own $100 \%$ of a U.S.-based life insurance company having acquired Pacific Guardian several years ago. It was just recently announced that they agreed to acquire Hawaiian Life from American General through Pacific Guardian. On a larger scale, Dai-Ichi made an investment of approximately $\$ 300$ million in Lincoln National, representing roughly a $10 \%$ ownership. This was very significant as it was the first major investment by a Japanese company in a U.S. life insurance company and, furthermore, this particular investment provides for joint business ventures. If the Japanese behave as they have historically, it would not be surprising to see several other Japanese companies follow Dai-Ichi's lead.

\section{New fundamentals in the U.S. financial services sector}

Let's look at the fundamentals in the U.S. financial services sector. This would include not only insurance companies but other financial service concerns such as banks and savings and loans. 


\section{Consumer sophistication}

Up on the list there we have consumer sophistication. Today's U.S. consumer clearly has a lower risk tolerance and demanding higher rates of return. Also, their time frame to realize these rates of return continually narrow.

\section{Deregulation and tax revision}

Deregulation has led to new products, cross industry competition and this, along with tax revisions, has resulted in a more level playing field.

\section{Changes in society}

The aging population, growing affluence, and the increased importance of the woman's role in business has led to new markets. On the other hand, concerns about AIDS, tort liability and health insurance with respect to not only availability - some would say entitlement - but, also, to affordability of coverage.

\section{Improved technology}

Everything is mechanized today. This mechanization has led to new marketing approaches. For example, through direct response marketing companies are able to make use of databases for targeting certain socio-economic groups in an efficient manner.

\section{Economic developments}

We've all read about the problems with below investment grade bonds - those rated at Baa or below - otherwise known as junk bonds, real estate problems, and the catastrophic costs of the bailout of the savings and loan industry. We have already committed to spend over $\$ 160$ billion and the amount will likely go higher. All of these developments have led to a growing emphasis on the importance of capital, and on the quality of that capital.

\section{Entry of industrial and foreign capital}

Certainly, what we are analyzing here is foreign capital entry but, also, we have seen industrial companies enter the financial services market. It's attractive, at least historically, because of the relative stability, the size of the market itself, and the growth potentials.

\section{Outlook}

We see that the outlook will mostly be the same, that junk bonds and savings and loans will take quite some time to heal. However, the historical attractiveness of this market may not be as strong as it once was given the recent failure of several large banks, savings and loans, and insurance companies.

\section{Consequences of the new fundamentals}

\section{Intensified price competition}

We continue to realize intensified price competition through the use of marginal pricing, cost reduction actions and improved productivity.

\section{Critical mass}

On the life insurance side, we are hearing the words "critical mass" thrown about. This is largely a problem for the small-to-medium size life insurance companies that are either not operating efficiently or are simply not generating a sufficient amount of new business to cover their expenses. Historically, these companies have been able to look the other way because of the large profits thrown off by their old blocks of business, but as these blocks of business wither away, the expense problems become more onerous. 


\section{Obsolescence}

Product lifecycles today are measured in months rather than years as was the standard in the 70's.

\section{Investments}

As pointed out earlier, there is a flight to quality, an increased emphasis on the safety of principle, and the use of asset liability matching to intelligently select assets that will provide cash flows similar to the liability cash flows.

\section{Massive consolidation}

We are seeing massive consolidation in order to achieve economies of scale, solve the critical mass problems previously referred to, increase operating efficiency, and gain access to a larger capital base.

\section{Growing emphasis on strategic planning}

Finally, there has been a growing emphasis on strategic planning. The need to compete on a cross-industry basis has dictated the need for broader management skills with the ability to achieve a sustainable competitive advantage at reasonable profit levels.

\section{Current status of the life and health market by product line}

\section{Individual life}

This line represents $25 \%$ of the total life and health premium dollars but has been declining since 1983. It still does enjoy tax advantages, including the deferral of tax on the inside buildup and the sheltering of death proceeds from ordinary income. However, there are growing concerns, we referred to some of the previously, such as critical mass for the small or medium-size companies, low or non-existent profits, an agency system that is expensive and cannot be controlled, and as previously mentioned, concerns about AIDS.

\section{Individual accident and health}

It represents only $5 \%$ of the total. Essentially products fall into one or two categories: (1) limited benefit plans where the maximum benefit and usually scheduled such as hospital indemnity plans and dread disease plans; or, (2) plans with benefits that are essentially unlimited including major medical and disability income. Profits for the limited benefit products seem to be okay with the results for the others mixed. Especially for the unlimited benefit plans, both underwriting and claims administration are extemely important.

\section{Home service}

Home service, otherwise known as debit or industrial, has been declining for certainly the last half of this decade and it is dominated by only a few large players.

\section{Variable products}

These products are still sold only by a few companies and of those that do sell them, most of the funds are directed into fixed interest accounts making them look and behave like general account products.

\section{Credit life and health}

Representing only $1.7 \%$ of the total, this product line is primarily controlled through captive arrangements. It is very heavily regulated and profit margins are low or nonexistent. 


\section{Group life and health}

This is the third largest category representing $20 \%$ of the total, $75 \%$ of which is medical. Most larger employers self-insure and this must be viewed as a competitor of insured plans. Other competitors are the Health Maintenance Organizations (HMO), effectively prepaid insurance arrangements, Preferred Provider Organizations (PPO) where providers will, through an arrangement with an insurance carrier or through a self-funded arrangement, provide services at reduced fees. The extreme PPO is the exclusive provider organization (EPO) which is similar to a PPO, but the institutions providing services are even much more limited than a PPO but the benefits tend to be higher.

In all of these, including insured plans, there has been a growing emphasis on managed care to control medical costs.

\section{Annuities}

This category represents $45 \%$ of the total. It has grown very significantly in the decade of the $80 \mathrm{~s}$ but it is a surplus user.

The types of plans include, on the individual side, tax-sheltered annuities marketed either through educational institutions or hospitals which qualify for tax preferred treatment, single premium deferred annuities, and single premium immediate annuities, either those issued in conjunction with settlement of court cases or those issued to fund lottery winnings. On the group side, we have guaranteed investment contracts which primarily are used to fund plans such as $401-\mathrm{Ks}$ and pension plans where a significant amount of money is invested for a specified period of time and at a specified interest rate. We also have guaranteed annuity contracts, or GACs, which are used to fund terminated pension plans; in other words, employees or retirees whose current or future benefits are known.

Clearly, investment performance is very important for companies writing annuities. Up until recently banks were able to compete with insurance companies through bank investment contracts or BICs. Banks had a distinct competitive advantage as BICs enjoyed FDIC insurance coverage but legislation was recently passed eliminating such coverage.

\section{Distribution}

On the traditional side, there is the career agency where historically agents were aligned with only one company. Certainly, within the last twenty-five years that alignment has eroded and even companies claiming to have career agency forces more than likely have their agents selling for other companies. Nevertheless, the expense involved with a career agency force has led to the growing importance of brokerage general agencies and personalproducing general agencies.

On the non-traditional side, as previously stated, banks have been direct competitors through the BICs on an "uninsured basis", and there have been several attempts by insurance companies to sell insurance products within banks without much success. Banks have also tried to enter the risk taking side but have thus far had their efforts met with strong opposition from the insurance industry as well as froin the Federal Reserve. ${ }^{1}$

\footnotetext{
${ }^{1}$ In June, 1991, the Second Circuit Court in New York vacated in August 1990 ruling by the Federal Reserve Board which had effectively blocked bank holding companies from taking advantage of a Delaware law expanding the insurance powers of state-chartered subsidiaries. State-chartered subsidiaries of bank holding companies in Delaware will be able to both sell and underwrite all lines of insurance under a decision last week by a United States Court of Appeals.
} 
Stock brokerage firms have sold annuities very heavily. Of course, there have been a few companies which have been very strong on direct response and, on the individual side, banks and several savings and loans have aligned with marketing houses to sell life insurance to cover, for example, mortgage balances, and as substitutes for certificatcs of deposit.

\section{Life insurers insolvencies $(1975-90)$}

Table 2:

Life Insurance Insolvencies

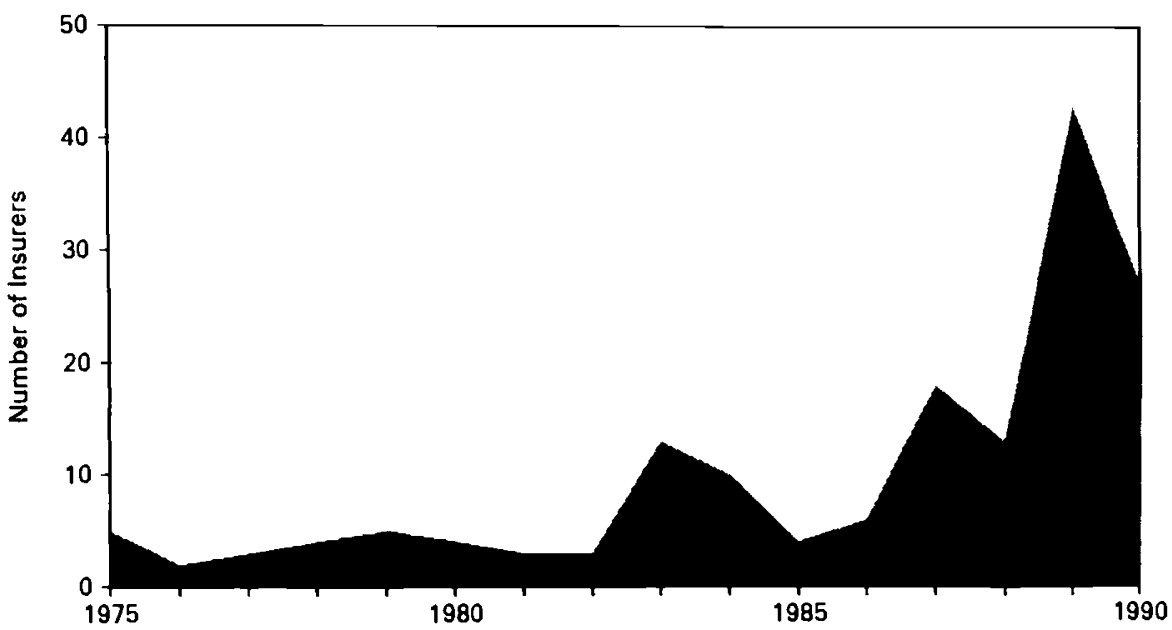

Source: NOLHGA, 1/28/91.

Table 2 charts the number of life insurer insolvencies over the last 15 years. Even as recently as the early ' $80 \mathrm{~s}$, the average annual rate was under five, with an alarmingly large number of 43 incurring in 1989. Admittedly, most of these are smaller companies and several of those were in group major medical; a very volatile line of business. However, all have heard about First Executive's life companies takeover by the California Commissioner and New York Commissioner, as well as the takeover of First Capital's life companies. There is a very real possibility that the amount of unpaid policyholder benefits from these companies, in particular First Executive's companies, could total more than $\$ 2.5$ billion.

\section{Life and health insurance guaranty association assessments (1975-89)}

Table 3 provides the Life and Health Insurance Guaranty Association Assessments. One can see that in 1989 the assessments were roughly $\$ 180$ million and that the assessments follow the number of insolvencies. Compare that to the $\$ 2.5$ billion estimate just mentioned and it is easy to conclude that the guaranty associations are not likely to cover $100 \%$ of this estimated deficiency. 
Table 3:

Life and Health Insurance Guaranty

Association Assessments (1975-89)

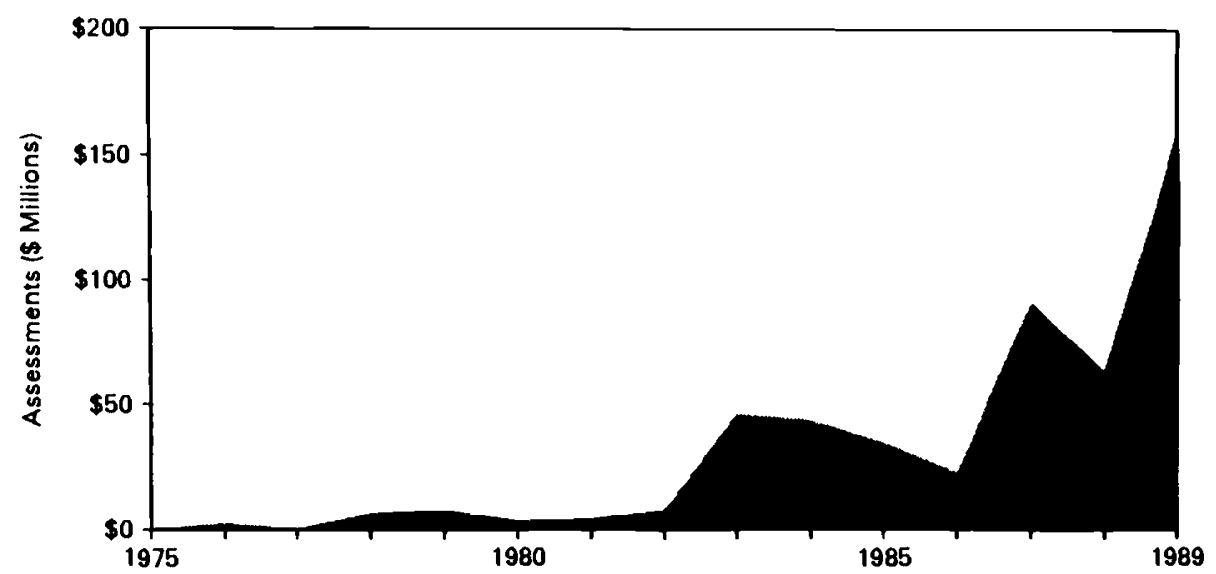

Source: NOLHGA, 1/28/91.

\section{Property and casualty market}

\section{Personal lines}

Moving over to the property and casualty side, we first take a look at the personal lines market. Here, the market is dominated by large captive agency companies and direct marketing companies representing over $65 \%$ of premium written. Although it did represent $46 \%$ of the industry's underwriting losses, it is viewed as a less volatile market. The winners in the personal lines market will be those which are both efficient at distributing and at operating.

\section{Commercial lines}

Commercial lines carriers, as opposed to personal lines carriers, are dominated by independent agency companies representing over $75 \%$ of net written premiums. It's viewed as a volatile line and the survivors in this line will be those with strong business relationships and the ability to maintain stable prices.

\section{Reinsurance}

The last line of business on the property and casualty side is reinsurance. Here, we've seen a significant consolidation through the combination of several insolvencies and withdrawals by others.

Demand is down as companies continually increase their own direct retention. The smaller and weaker reinsurers are generally being forced out as selection of reinsurers emphasizes financial strength today more than it ever has in the past. 


\section{Implications for the property and casualty insurance market}

What are the implications for the property and casualty insurance market?

\section{Underwriting cycle}

The underwriting cycle is still here. We will continue to experience cycles in future years; however, the depth and severity of the last cycle clearly demonstrated that maintaining market share just for the sake of maintaining market share by cutting prices was not a viable strategy. Instead, a competitive advantage must be sustainable.

\section{Importance of capital}

We have to underline the importance of capital. Consumers now demand that their insurance companies be financially strong and product managers are now concerned about and examine catastrophic exposures of insurance carriers.

\section{Tax reform}

The Tax Reform Act of 1986 had a significant impact on property and casualty companies in that it did require them to discount loss reserves and only $80 \%$ of unearned premium reserves were deductible. Additionally, $15 \%$ of tax exempt income became taxable.

\section{Inadequate reserves / solvency issues}

The industry is still viewed as under-reserved, but the degree of understatement is certainly subject to debate and $100 \%$ recognition of all liabilities would probably result in further insolvencies.

\section{Entry of new competitors}

There continues to be a stream of new competitors in the property and casualty market even though it is saturated. Foreign companies historically have been drawn by what was viewed as the relative stability of the U.S. economy and, additionally, their need to have a U.S. presence if they are going to be a major player in the international market.

\section{Tort reform}

There have been many initiatives produced with little in the way of reform resulting from these initiatives. Clearly, there is a need for tort reform when viewed from the insurance industry's perspective, but the recent consumer movements would likely, at least in the foreseeable future, thwart any actual or substantive reform.

\section{Availability / affordability reform}

It has become a real problem for lower income families just to be able to afford automobile insurance. There have been attempts at reducing insurance rates through legislation with the most famous probably being California's Proposition 103 which required a rate reduction to $20 \%$ below the November, 1987 levels. To date, this rate rollback has not been put in place, but California's newly elected insurance commissioner has indicated that he wants the intent of Proposition 103 to go forward and so "the jury is out" as to what the likely outcome will be.

\section{Antitrust challenges}

Concerns about availability and affordability have raised debates as to how rates should be established and how they should be regulated. Regardless of the outcome of the 
various attempts to amend or repeal the McCarran-Ferguson Act, companies will have to establish rates morc independently. Evidence of this was the Insurance Scrviccs' Office decision not to promulgatc advisory rates for its member companics.

\section{Failed promises}

A report to Congress in February, 1990, by the Housc Subcommittee on Oversight titled Failed Promises concentrated primarily on the property and casualty insurance industry and was generally vicwed by the industry to be overly pessimistic. However, it did contain issues and conclusions which cannot be ignorcd. These issues arc:

\section{Delegated management authority}

The industry has relicd fairly heavily on managing gencral underwritcrs who have a natural conflict of interest between how they arc compensated and the interest of the insurance carriers. Additionally, these agents sometimes do not have the abilities to deal those delcgatcd responsibilities.

\section{Holding companies and affiliates}

The report expressed concern about the highly leveraged nature of holding companies and whether or not these holding companies or their affiliates might withdraw quality assets out of their insurance subsidiaries.

\section{Reinsurance}

The report noted that neither their financial stability nor their dependability were considered, at least historically, in the selection of reinsurers. The report further stated that the states have not been successful in resolving problems associatcd with rcgulating reinsurance.

\section{Unreliable information}

The information used by state regulators is largely unreliable bccause it is provided by the insurance companies themselves with no verification by regulators, auditors, or qualified actuaries. Additionally, oftentimes the information is outdated.

\section{Insufficient regulation}

State regulation, the report noted, suffers from inadequate resources, lack of coordination, infrequent financial examination, and again, unreliable information.

\section{Enforcement}

The report concluded that the present system of regulation devotes insufficient cfforts to investigating insolvcncies and punishing responsible parties. This is the consequence of rcsource deficiencies, procedural or jurisdictional problems, limited penaltics and, finally, in some cases, unwillingncss to pursue wrongdoers.

\section{Competitive position of U.S. insurance industry}

Hcrc are a couple of comments about the competitive position of the U.S. insurance companies:

\section{Strengths}

On the strength side, it does have a very strong distribution system. It also has a strong capital position, at least when comparcd to banks and savings and loans and, on the life insurance side, products continue to enjoy a tax favored status. 


\section{Weaknesses}

Its weaknesses include a vulnerability ot low cost competition. As I pointed out earlier, it does have a strong distribution system, but that distribution system is reasonably expensive. A strength on the life side was its tax favored status which would be viewed as a weakness if that were to be lost. Additional wcaknesses include lack of agent loyalty and, finally, capital constraints for mutual companies.

\section{Regulation of U.S. insurance companies}

Insurance companies in the United States arc subject to regulation by several regulatory bodics.

\section{McCarran-Ferguson Act}

This Act gave primary responsibility to the states and, as wc previously mentioned, has been subject to challengc from time to time.

\section{National Association of Insurance Commissioners}

The NAIC is the coordinating body amongst states but its ability to achieve uniformity in legislation is virtually impossible because of the autonomous nature of the state regulatory bodies.

\section{Approval requirements}

Generally, regulation of life and annuity ratcs is nonexistent. However, credit, health, and property and casualty insurance is subject to rate approval and, for health insurance, there are loss ratio requirements.

\section{Extra-territorial laws}

Companies licensed in New York are subject to cxtraterritorial jurisdiction and as a result, most companies that wish to operate in New York do so through a separate subsidiary for New York operations. Some states, including California, Florida and others, have "commercially domiciled" statutes which allow extraterritorial jurisdiction under ccrtain circumstances.

\section{Variable products}

These products are subject to regulation by both the Securities and Exchange Commission and state security laws in addition to the state insurance laws.

\section{Other laws}

There are laws that limit investments, dividends to shareholders, and transactions with affiliates. These are in addition to laws requiring licensure as an insurance company, licensing of agents, and approval of policy forms.

Form filing

A "Form A" filing which addresses the characteristics and plans of a buycr must be filcd whenever there is a $10 \%$ or more change in control or when there is, in some cases, the acquisition of a substantially large block of business.

\section{Policyholder protection}

There is no fedcral fund that exists to protect policyholders from any losses due to insurance company insolvencics. Therc are, however, guaranty associations in most 
jurisdictions that provide for limited coverage due to insolvencies through an assessment mechanism. For life and health companies, all jurisdictions have such an association except for Colorado, Guam, Louisiana, New Jersey, ${ }^{2}$ the Virgin Islands, and Washington D.C. For property and casualty companies, only Guam and the Virgin Islands do not have guaranty funds.

\section{Financial reporting}

Generally, there are two forms of financial reporting - some might argue three, with the third being taxes - but the two that we have here are statutory accounting principles (SAP) and generally accepted accounting principles (GAAP).

\section{$S A P$}

This is the method of accountig used in filings with state insurance departments. Generally, everything is expensed and conservative assumptions are used in establishing liabilitites.

\section{GAAP}

Under GAAP, acquisition costs are capitalized rather than expensed and amortized over the lifetime of business issued. This method is viewed as being much more realistic in terms of assumptions that are used. Whenever a company or a block of business is acquired, assumptions are restated under what is called "purchase GAAP" to reflect current experience rather than experience anticipated at issue as in GAAP.

\section{State and federal taxation}

The key issues on taxation are the following:

\section{Life and health companies}

Life and health companies have a federal tax rate of $34 \%$ where the tax base was effectively statutory income with some adjustment for mortality and interest assumptions. Effective October 1, 1990, legislation was passed requiring that a deferred acquisition cost asset be established. This is determined as a flat percentage of premium varying by product line which is capitalized and amortized generally over a ten year period. Mutual companies are additionally taxed on their equity base at what is called a differential earnings rate in an attempt to nullify the tax free return on equity which is implicit in policyholder dividends and, hence, put stock and mutual companies on a more equal footing. Finally, smaller companies enjoy a small company deduction which can significantly lower the effective tax rate to approximately $13 \%$.

\section{Property and casualty companies}

On the property and casualty side, the same federal rate exists, and we have already mentioned the 1986 changes which affected legislative discounting of loss reserves and taxation of $20 \%$ of unearned premiums and the tax on tax-exempts.

\section{State and local taxes}

At the state and local level, there are premium taxes of $1 \%$ to $4 \%$. Some states do impose income taxes and although it is rare, some municipalities also impose premium taxes.

2 In July, 1991, New Jersey passed legislation effective January 1, 1991, authorizing a guarantee fund for life and health policyholders in its state. 


\section{Strategic rationale}

Why make a U.S. insurance acquisition? To begin with, the U.S. insurance market represents $40 \%$ of the worldwide life and health market and $50 \%$ of the worldwide property and casualty market. It is relatively easy to enter, particularly compared to some countries such as Japan. Overall the U.S. economy is viewed as stable although, admittedly, there is some instability within the insurance industry today. Nevertheless, the longterm growth prospects are good, but not necessarily for all lines.

U.S. management views foreign ownership as favorable compared to U.S. ownership, in that foreign managers tend to be more willing to leave management alone and to adopt a longer term perspective.

\section{U.S. insurance market}

\section{Performance}

Looking at a ten year performance of life and health, property and casualty, multi-line and the insurance industry overall compared to the major indices in the United States, we can see in table 4 that over a ten year period ending in 1989, the insurance industry outperformed all of the other major indices by $249 \%$ versus the Dow's $228 \%$. There were clearly mixed results by segment as the life and health industry had $241 \%$ over this same period whereas property and casualty was a clear winner at $381 \%$. Multi-lines have typically lagged behind the other two major categories where multi-line is defined to include both life and property/casualty companies within the same holding structure.

Table 4:

U.S. Insurance Market

Percentage Gains in Stock Prices

\begin{tabular}{|l|c|c|c|c|c|}
\hline Time Period & $1989(2)$ & $1988(2)$ & $1987(2)$ & Year 5(3) & Year 10(3) \\
\hline Life/health (1) & $28 \%$ & $25 \%$ & $-21 \%$ & $71 \%$ & $241 \%$ \\
\hline Property/casualty (1) & 44 & 11 & -7 & 145 & 381 \\
\hline Multiline (1) & 31 & 3 & -15 & 59 & 135 \\
\hline Insurance/industry (1) & 37 & 11 & -13 & 98 & 249 \\
\hline S \& P 500 & 27 & 12 & 2 & 111 & 227 \\
\hline NYSE Composite & 25 & 13 & 0 & 102 & 215 \\
\hline Dow Jones 30 industrials & 27 & 12 & 2 & 127 & 228 \\
\hline CPI All Urban & 5 & 4 & 4 & 20 & 64 \\
\hline
\end{tabular}

Sources: A.M. Best, Monthly Labor Review.

(1) A.M. Best Stock Indices

(2) Calendar year only

(3) To December 31, 1989.

The five year return is slightly different with the industry lagging somewhat behind the major indices at $98 \%$ versus $127 \%$ for the Dow. Again, property and casualty emerged as the stellar performer within this period at 145\%. 1987 was a disastrous year through the combined effects of the October stock market crash, a softening of the property and 
casualty market, and huge losses in group health led to a relatively poor performance in all sectors of the insurance industry. 1988 was a rebound year with the comparable rcsults of the other major indices: $11 \%$ for the industry compared to $13 \%$ for the New York Stock Exchange composite. 1989 was certainly a very good year with the industry outperforming the other indices by $10 \%$.

\section{Table 5:}

U.S. Insurance Market

Five-Year Average Performances

Through December 31, 1990

\begin{tabular}{|l|c|c|}
\hline & $\begin{array}{c}\text { Return on } \\
\text { Equity }\end{array}$ & $\begin{array}{c}\text { Growth in } \\
\text { Sales Revenues }\end{array}$ \\
\hline Life/health companies (18) & $11.1 \%$ & $9.7 \%$ \\
\hline Property/casualty companies (22) & 18.0 & 14.1 \\
\hline Diversified insurance companies (25) & 15.3 & 13.0 \\
\hline Total insurance group (65) & 14.8 & 12.5 \\
\hline All-industry medians & 14.6 & 11.3 \\
\hline
\end{tabular}

Source: Forbes, January 7, 1991.

Forbes' January 7, 1991 issue gives us a more recent picture. You can see that, compared to all industries, the insurance five-year average growth in sales revenues $(12.5 \%)$ exceeded all of the all-industry medians $(11.3 \%)$. Within the industry, life companies had the lowest results at $9.7 \%$ and, again, with property and casualty companies the superior performers at $14.1 \%$. Similar comments can be made on the five-year average return on equity which shows that the insurance group outperformed the other all-industry medians, $14.8 \%$ and $14.7 \%$, respectively, with the life companies once again dead last at $11.1 \%$.

\section{Approach}

How do you make an acquisition? What approach do you take? Do you buy a stock company or do you, as Royal did with Maccabees, do a structured demutualization? Regardless of the choice you make, the typical first step is to form a U.S. holding company and assemble a team of experts who are ready to move quickly. This team should include internal advisors as well as external advisors such as investment bankers, actuaries, accountants and lawyers.

It is always recommended that the first approach be on a friendly basis as hostile takeovers are very expensive and lengthy. Again, one can only guess as to whether or not BAT's acquisition of the Farmers Group would have ultimately been successful had it continued on a hostile basis.

\section{Transaction Prices}

What have prices been? These are prices of companies for which there are publicly available GAAP financials. Generally speaking, these represent about one-third of the total transactions that actually take place with the others being either private transactions for which only statutory data is available or the prices are not disclosed. 


\begin{tabular}{|c|c|c|c|c|c|c|c|c|c|}
\hline & 2 & & 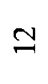 & $\stackrel{\circ}{-}$ & $=$ & & $\Rightarrow$ & $\stackrel{f}{-}$ & $\exists$ \\
\hline & \& & & $\beth$ & $=$ & $\simeq$ & & $\simeq$ & 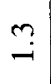 & $=$ \\
\hline & $\stackrel{\infty}{2}$ & & 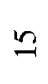 & $\stackrel{\sim}{-}$ & 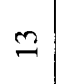 & & $\infty$ & $\stackrel{\square}{\square}$ & $\stackrel{\varrho}{ }$ \\
\hline & $\hat{\infty}$ & & 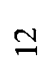 & $\because$ & 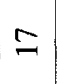 & & $m$ & $\stackrel{N}{-}$ & 9 \\
\hline & $\begin{array}{l}\infty \\
2 \\
2\end{array}$ & & $\stackrel{0}{-1}$ & $\stackrel{\sim}{-}$ & $\stackrel{\infty}{\sim}$ & & 0 & $\stackrel{0}{-}$ & 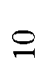 \\
\hline & $\stackrel{2}{2}$ & & $\exists$ & $\stackrel{\Im}{-}$ & $a$ & & $r$ & $\stackrel{n}{?}$ & $\bar{\lambda}$ \\
\hline 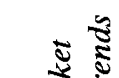 & \$ా & & $\simeq$ & $\stackrel{N}{-}$ & $\mathscr{2}$ & & $r$ & $\stackrel{0}{-}$ & 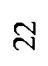 \\
\hline 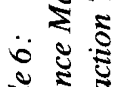 & $\stackrel{2}{\infty}$ & & $\infty$ & $\stackrel{0}{-}$ & 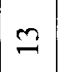 & & $\forall$ & $\stackrel{\circ}{\sim}$ & $\mathscr{C}$ \\
\hline ब. & $\stackrel{2}{2}$ & & $\Xi$ & $\stackrel{\square}{-}$ & 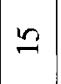 & & $r$ & $\stackrel{N}{-1}$ & $a$ \\
\hline$S \mathscr{Z}$ & $\stackrel{\infty}{2}$ & & $\bar{\sim}$ & $\stackrel{9}{-}$ & \pm & & $\nabla$ & I & $\cong$ \\
\hline & $\stackrel{8}{2}$ & & $=$ & $\stackrel{\circ}{i}$ & $\because$ & & 0 & $\stackrel{\circ}{i}$ & $=$ \\
\hline & & 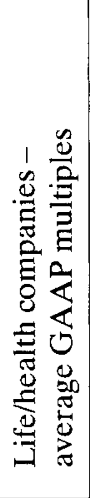 & 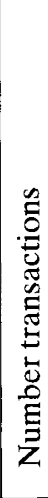 & 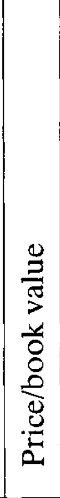 & 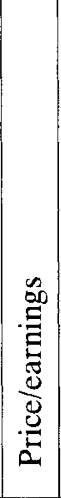 & 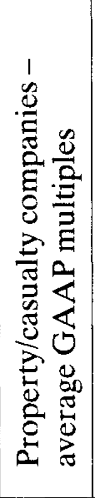 & 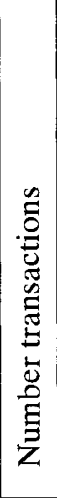 & 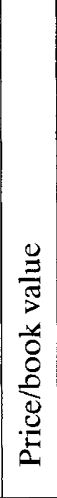 & 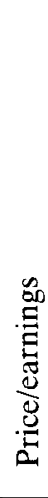 \\
\hline
\end{tabular}


Taking a look at the life/health side, the highest prices compared to the GAAP book value preceded 1984, with 1984 and subsequent years hovering in the 1.2 times GAAP book value range. As you can see, in 1989 it was 1.1 times and in 1990, 1.0 times. Price earnings have been more stable, but this probably doesn't signify anything since if prices go down and earnings go down, the ratio can remain the same.

Looking at property/casualty - again, prices were relatively high pre-1984 but not as consistent as life/health prices with 2 times in 1983, and only 1.2 times in 1982. Also, the post 1983 trend that we saw for the life/health side is not evident on the property/casualty side and is reflective of the cyclical nature of property/casualty results. In fact, the highest multiple of this post 1983 period was 1990 with a 1.7 times GAAP book multiple.

In pricing an acquisition, companies may initially be forced to use only publicly available data. However, it is strongly recommended that, through a due diligence review, an actuarial appraisal of economic values or loss reserve review including sensitivity tests on such variables as mortality, lapses, expenses, loss ratios, and interest earnings be performed before an actual transaction takes place. This is not to say that transactions do not take place without appraisals. Some of the largest transactions were made using only public data and, in some cases, by relying only on stock prices. Nevertheless, an appraisal is recommended and usually, in a friendly situation, it can be accomplished.

What can one conclude from all of this? It seems clear that in order for a company to operate on an international basis at some point, a U.S. acquisition becomes very important. Therefore, those that want to fit a U.S. company into their international strategy must develop and maintain a good understanding of the fundamentals and dynamics of the U.S. insurance business. Not to do so may result in unsound decisions. Those who wish to make all acquisition will only be successful if they are prepared to move quickly whenever the opportunity arises.

\section{U.S. life and health market}

We shall deal now with the composition of the life and health market.

\section{Premium growth rate}

Taking a look at premium growth over the decade of the ' $80 \mathrm{~s}$, we can see an average annual increase of $10.4 \%$, with a decrease of $8.8 \%$ in 1983 due mainly to an entrenchment in annuity writings from the high levels in the immediate preceding years. The sharp jump in 1986 to $24.5 \%$ was largely the result of reclassification of certain types of annuity writings.

\section{Asset growth rate}

The average annual increases have been $11.8 \%$ through the ' 80 s.

\section{Capital and surplus growth rate}

Capital and surplus grew at an average annual rate of $10.4 \%$ for the decade representing $6.4 \%$ of total assets and $35 \%$ of total premiums for 1989 .

\section{Stock and mutual companies}

According to the American Council of Life Insurance (ACLI), of the roughly 2300 U.S. life and health insurance companies, approximately $95 \%$ were stock and $5 \%$ were mutuals. 
However, when looking at the 1988 statistics on life insurance in force, mutual companies have $38 \%$ of life insurance in force, with stock companies at $62 \%$.

A similar picture emerges for policy reserves for 1989 , with mutual companies having an even larger share at $44 \%$.

Premium income by line

The vast majority of growth in premium, as previously noted, has come from annuities, with health being reasonably strong and life, although 1989 exceeds 1980 's level, it is less than 1987's level.

Table 7:

U.S. Life and Health Market

Premium Income by Line

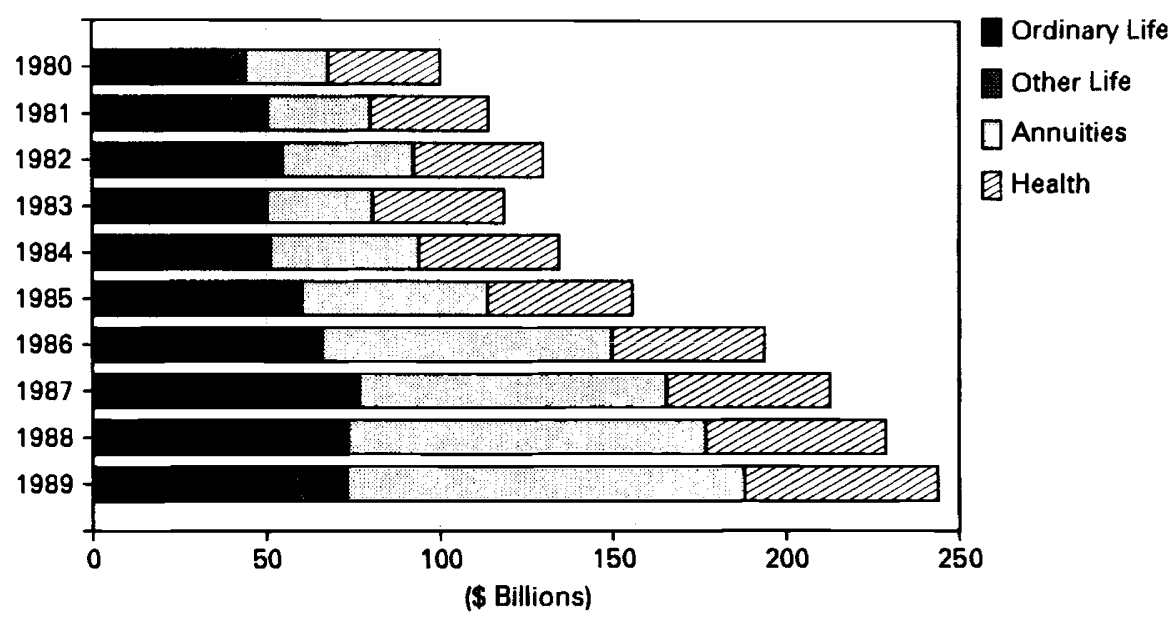

Source: American Council of Life Insurance

Distribution of assets by company size

The top twenty-five fleets of companies control $65 \%$ of the assets with fleet defined as companies within the same holding company structure or otherwise affiliated. The next 25 fleets control $14 \%$ of the total assets and all of the remaining out of the 2300 companies control $21 \%$.

\section{Distribution by premium income}

The picture for premium income is similar, with the top 25 controlling $51 \%, 18 \%$ for the next 25 , and the remaining companies $31 \%$. 


\section{Voluntary termination or lapse rates}

For those policies less than two years old, the peak occurred in 1983 at $25.1 \%$ consistent with the high level of term sales occurring in the early ' 80 s. This compares to the 1989 level of $18.8 \%$ which represented the lowest level of the decade. For policies more than two years old, the peak occurred in 1985 at $10.3 \%$ and has generally declined since then. The 1989 level of over $6 \%$ is still significantly above the historical levels of $4 \%$ in the 1960 s and 1970s.

Table 8:

\section{U.S. Life and Health Market}

Voluntary Termination Rates - Ordinary Life

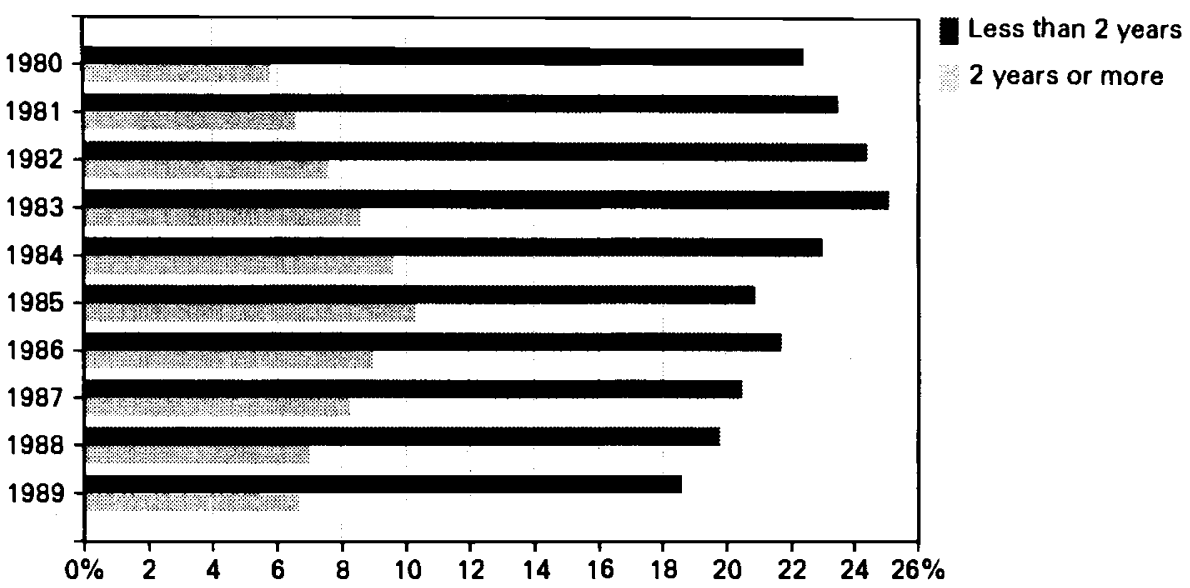

Source: American Council of Life Insurance.

\section{U.S. property and casualty market}

Net written premium growth rate

Probably the most telling story we can see here is the cyclical nature of the business. A hard market beginning in 1985 is evident by comparing 1984 to 1985 , and we see a softening of the market beginning in 1987 by comparing 1986 and 1987. This softening continues through 1989 (see Table 9).

\section{Assets growth rate}

The huge growth in 1985 and 1986 was, in additional to normal asset growth, a result of additional capital entering the market (see Table 10).

\section{Capital and surplus growth rate}

1984 shows very heavy losses which generated a hardening of the market, and we can see the effects of the capital infusions of 1985 and 1986 and the price increases from 1984 . Again, a softening is evident with the lower increases in 1987 and beyond (see Table 11). 
Table 9:

U.S. Property and Casualty Market

Growth Rate-Premium (Net Written)

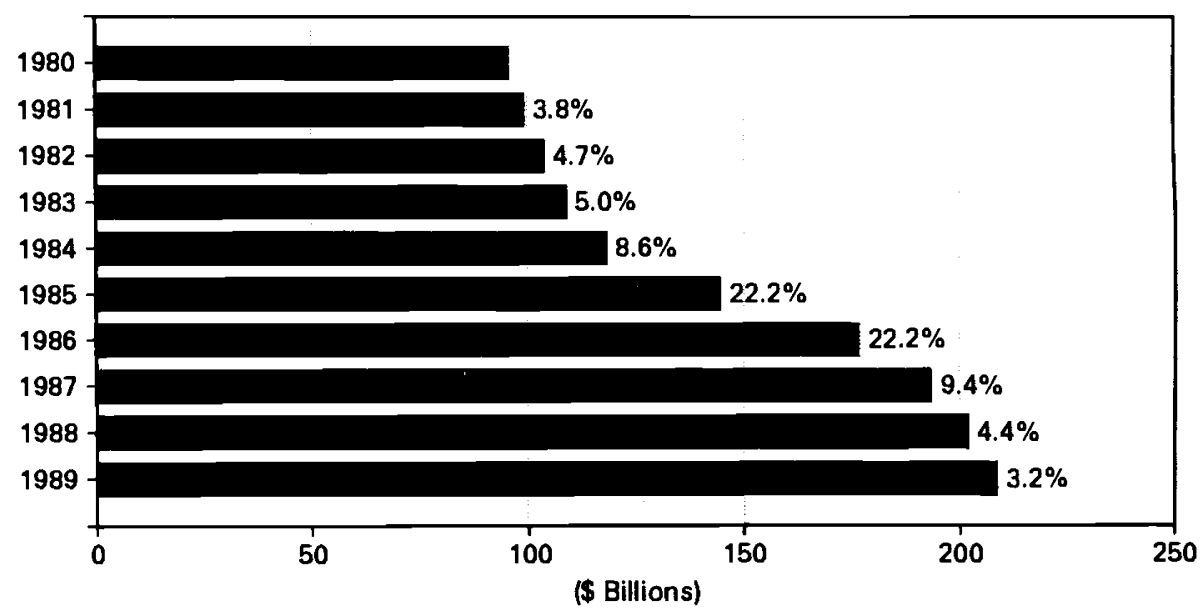

Source: A.M. Best's Aggregates \& Averages.

Table 10:

U.S. Property and Casualty Market

Growth Rate - Assets

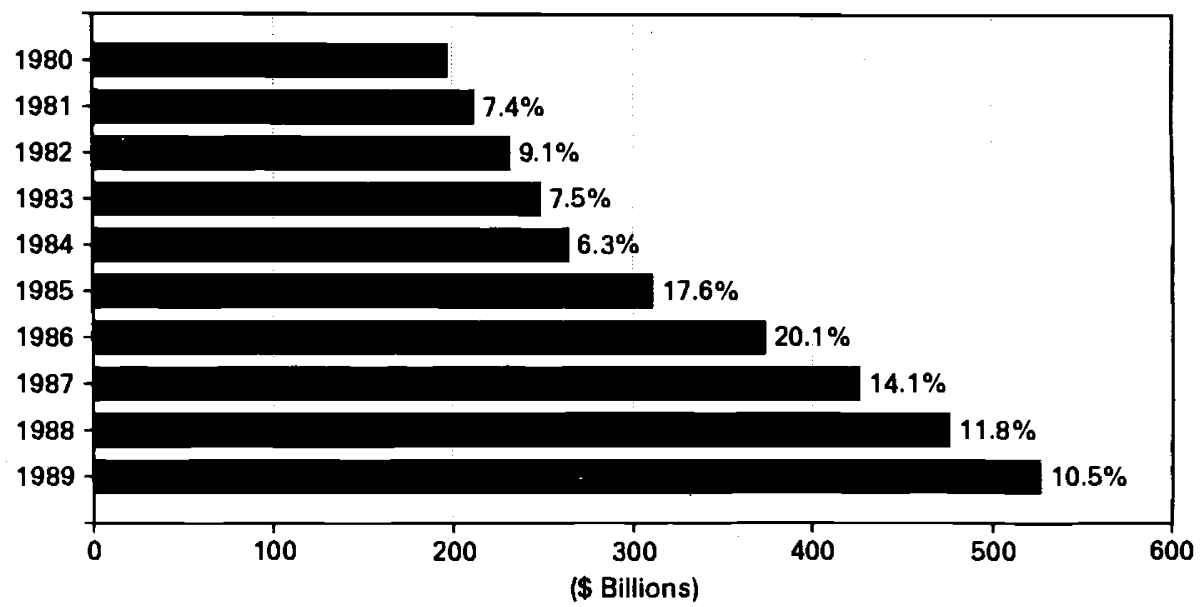

Source: A.M. Best's Aggregates \& Averages. 
Table 11:

U.S. Property and Casualty Market

Growth Rate - Surplus

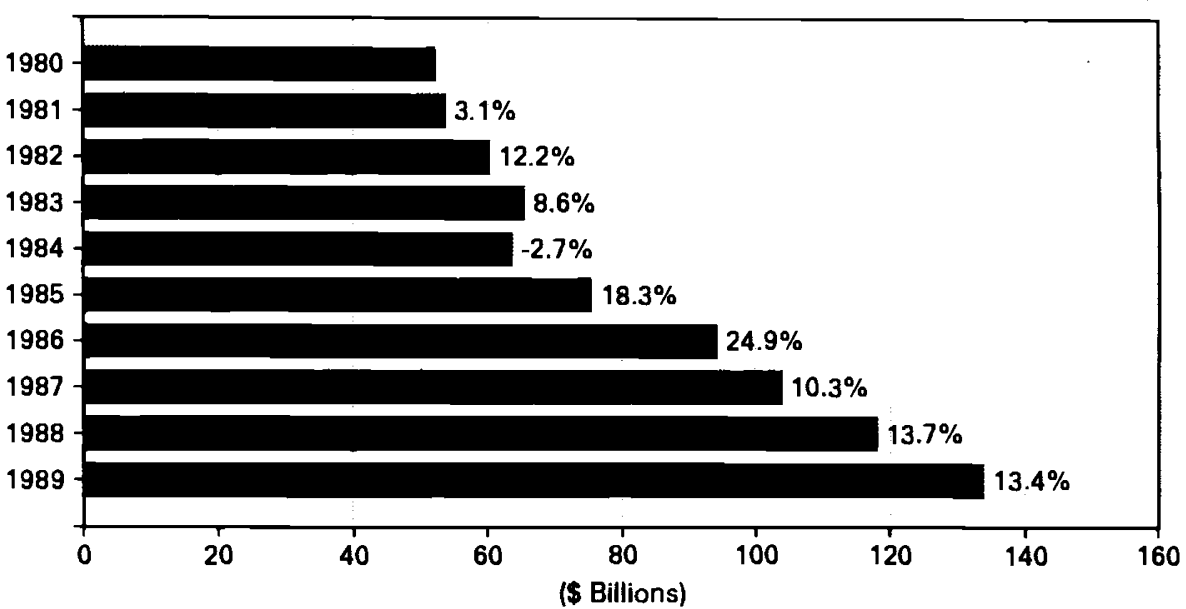

Source: A.M. Best's Aggregates \& Averages.

Taking a quick look at market share:

Type of Company

At the end of 1989 , stocks represented the vast majority at $69 \%$, with mutuals at $25 \%$, and reciprocals, $6 \%$.

\section{Distribution system} dent.

By distribution system, $43 \%$ of the market is direct or captive, and $57 \%$ is indepen-

\section{Product / distribution}

Personal lines in 1989 represented $45 \%$ of the market, with commercial lines representing $55 \%$.

As discussed earlier in the current status of the industry, by splitting the market between personal and commercial one can see that roughly $63 \%$ of the personal is controlled by direct or captive with the opposite on the commercial side with independents controlling $75 \%$ (see Table 12).

\section{Distribution of major lines - premium mix (1989)}

The next table 13 showing distribution by premium mix has personal auto as the largest at $21.1 \%$. Workers compensation is in second place at $13.5 \%$. The smallest category is medical malpractice at 2.0\%. CMP stands for Commercial Multi-Peril (see Table 13). 
Table 12:

U.S. Property and Casualty Market

Market Share (1989)

Product/Distribution

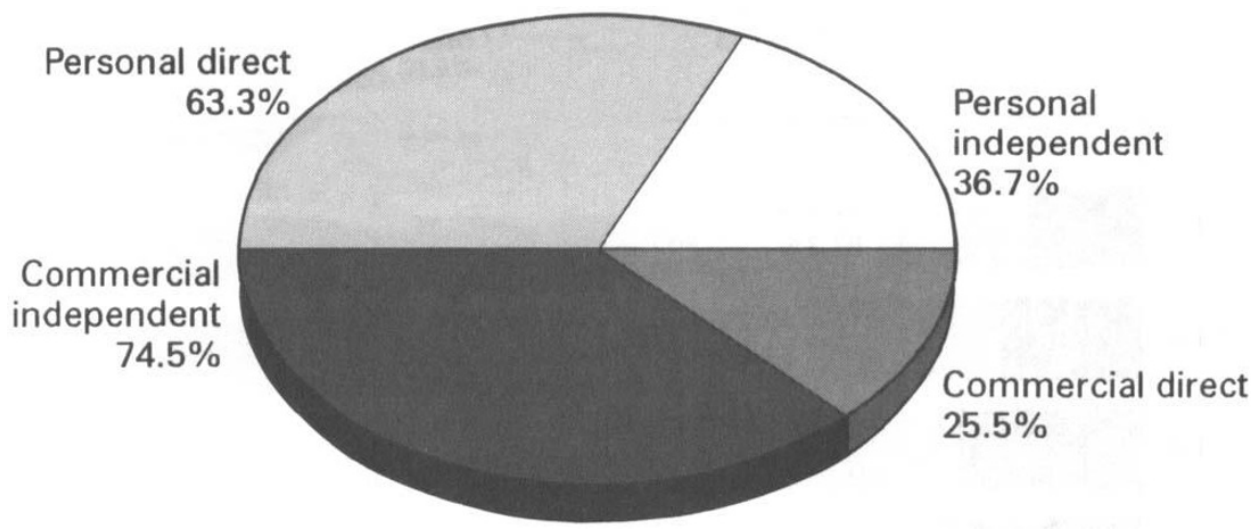

Source: A. M. Best's Agreegates \& Averages.

Table 13:

U.S. Property and Casualty Market

Distribution Major Lines - Premium Mix (1989)

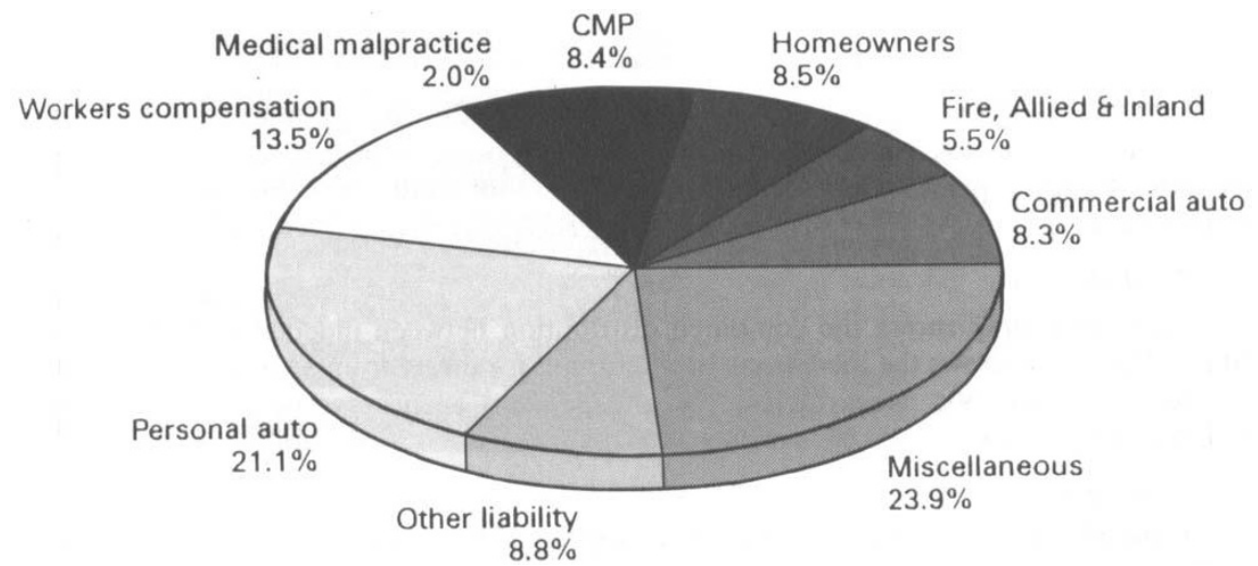

Source: A. M. Best's Aggregates \& Averages. 


\section{Personal lines}

Tracking the growth of the personal lines market we can see in Table 14 that the direct distribution has increased from $57.3 \%$ in 1980 to $63.3 \%$ in 1989 .

\section{Table 14:}

\section{U.S. Property and Casualty Market}

Market Share - Personal Lines

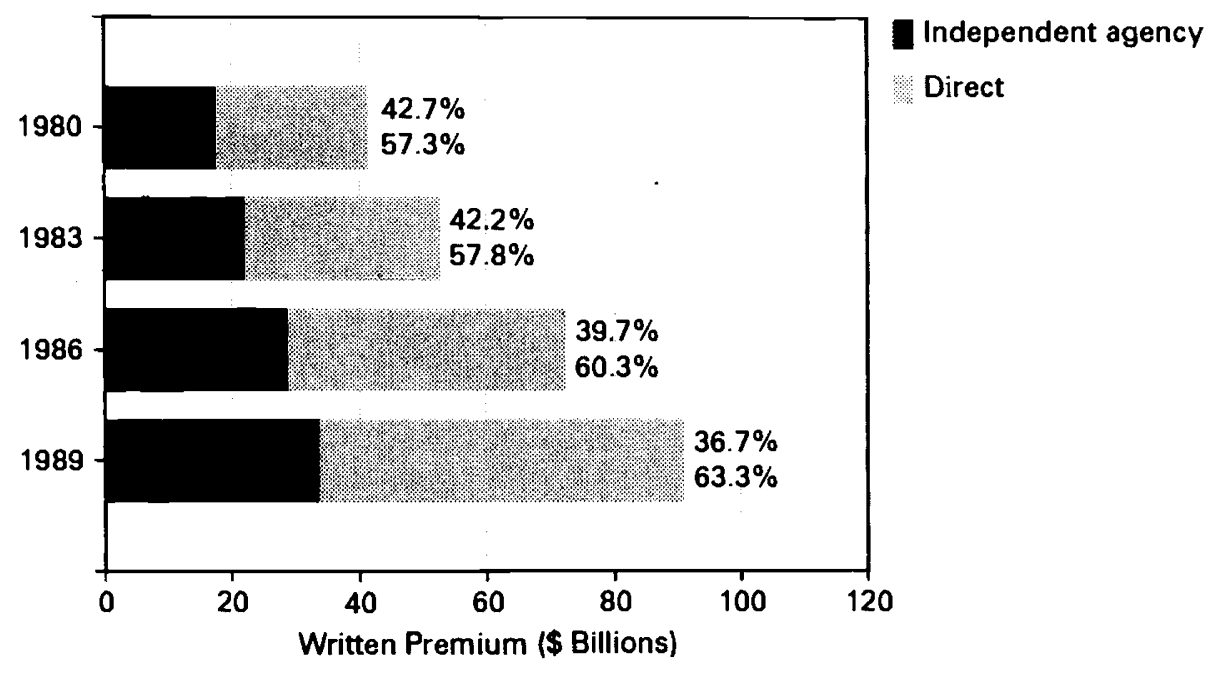

Source: A. M. Best's Aggregates \& Averages.

\section{Commercial lines}

Again, the direct is increasing, though much more slowly from $22.3 \%$ to $25.5 \%$ during the ' 80 s. As noted previously, independent agencies still control the vast majority of this marketplace.

\section{Total all lines}

Table 15 simply shows the combined distribution between independent agency and direct. This again shows the increase in market share for direct from $38.8 \%$ to $42.8 \%$ over the decade of the ' $80 \mathrm{~s}$. Nevertheless, the independent agency system still controls the majority of the market.

\section{Leading writers}

Table 16 reflects the distribution between the top 25 fleets and the next 25 fleets. There has been very little change over the decade, with the top 25 consistently controlling around $60 \%$ and the next 25 controlling $15 \%$ of the market. 
Table 15:

U.S. Property and Casualty Market Market Share - Total All Lines

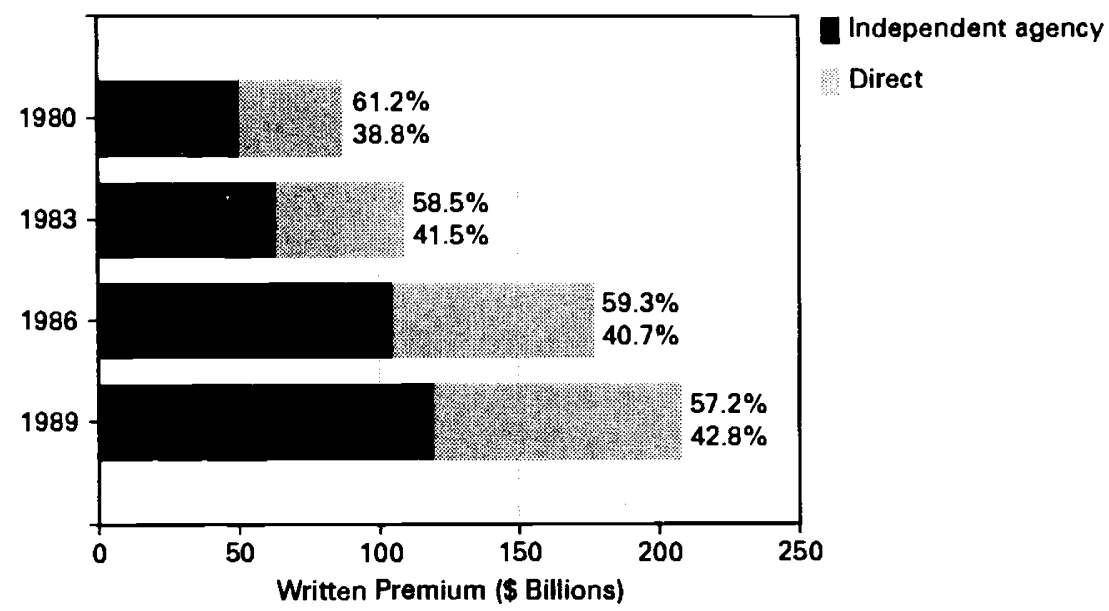

Source: A.M. Best's Aggregates \& Averages.

Table 16:

U.S. Property and Casualty Market Market Share - Leading Writers

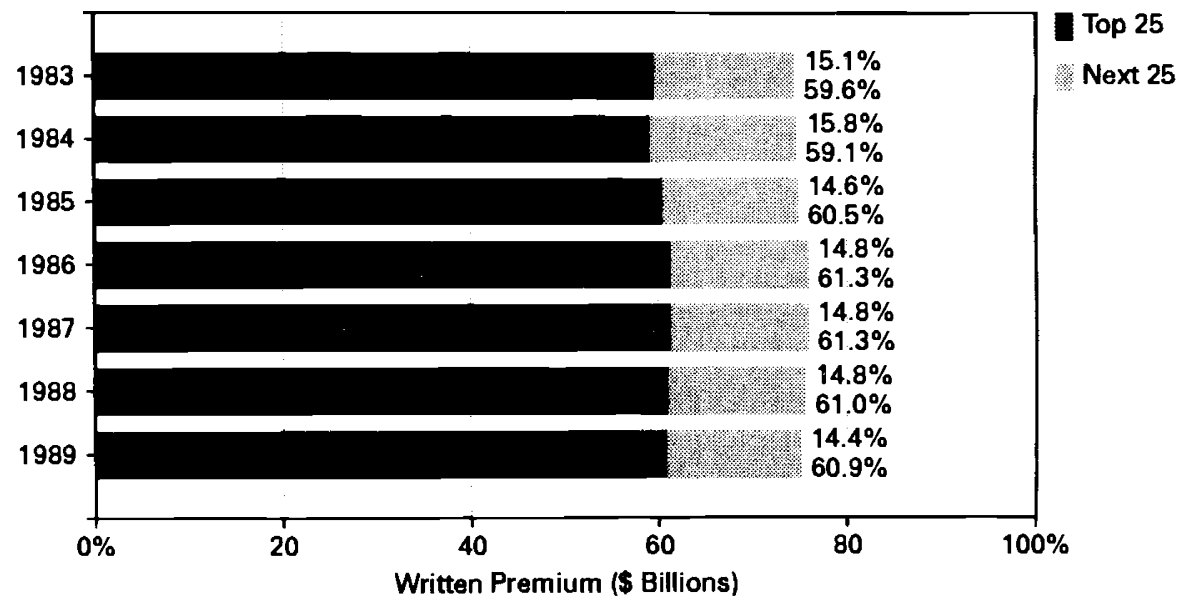

Source: A.M. Best's Aggregates \& Averages. 


\section{U.S. reinsurance market}

\section{Premium mix}

Clearly, treaty represents about $80 \%$ of the total premiums for 1989 . Within this, property is at about $36 \%$ which is down from $41.8 \%$ in 1987 (Table 17).

\section{Table 17:}

\section{U.S. Reinsurance Market}

Premium Mix (1989)

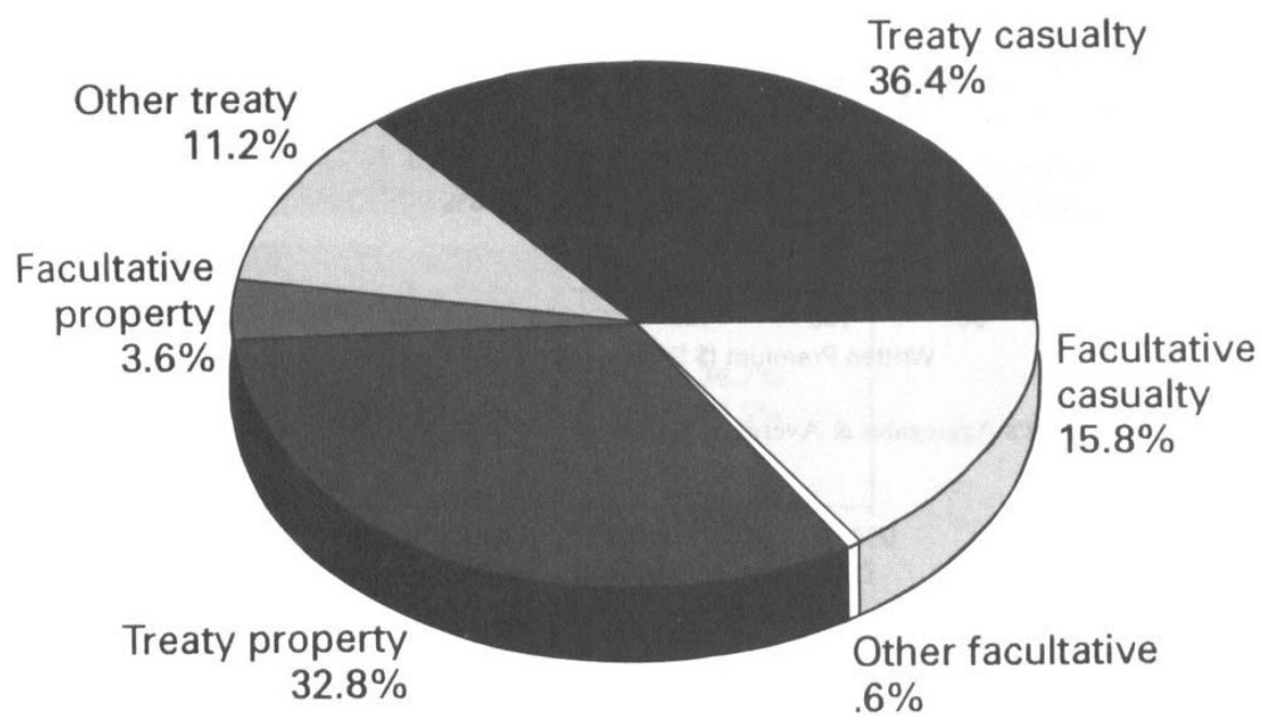

Source: Reinsurance Association of America.

\section{Type of reinsurer}

Here, we take a look at the marketplace split by type of reinsurer - professional reinsurers or reinsurance departments of direct writing companies or unlicensed reinsurers. Combined, professional reinsurers and reinsurance departments have lost over $11 \%$ of the market share to unlicensed reinsurers from 1979 through 1988. Most of those losses come from reinsurance departments, having dropped market share from $19.8 \%$ to $10.4 \%$ (Table 18).

\section{Leading writers}

Looking at the top ten and the next ten leading writers, one can see that at year end 1988 , the top twenty controlled $80 \%$ of the market compared to $64 \%$ in 1983 . These large increases have been mostly attributable to the withdrawals by companies from the marketplace (Table 19). 
Table 18:

U.S. Reinsurance Market

Net Written Premium - Type of Reinsurer

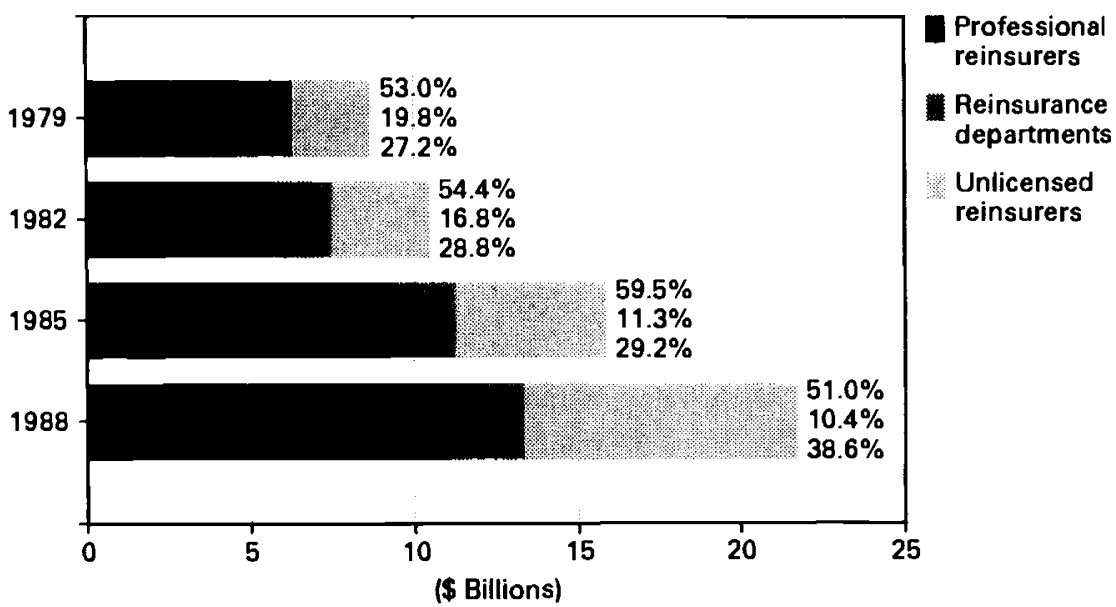

Source: Reinsurance Association of America.

Table 19:

U.S. Reinsurance Market

Market Share - Leading Writers

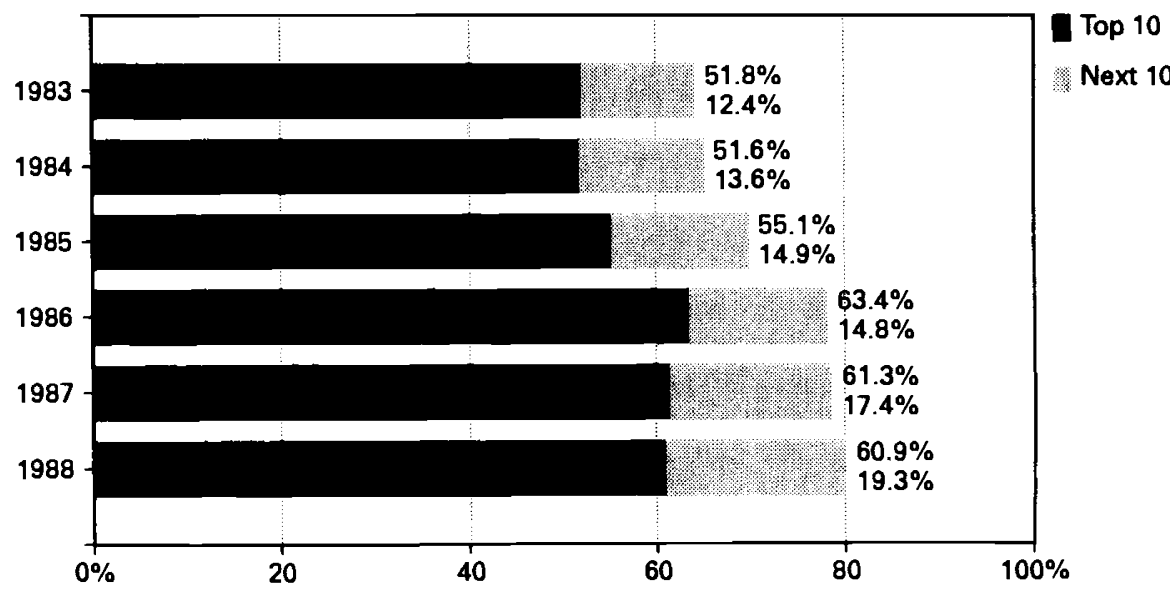

Source: Reinsurance Association of America. 